\title{
Rational Reflection on the "Layered-Teaching-in-One-Class" for Basic Computer Education in Accounting Vocational Colleges
}

\author{
Wang Fang \\ Chongqing Business Vocational College, Chongqing, China \\ cqszyzcp@163.com
} Keywords: vocational college, accounting college, basic computer education, the
layered-teaching-in-one-class.

\begin{abstract}
It is an important measure to conduct the layered-teaching-in-one-class reform for basic computer education. Starting from the unique features of students and the characteristics of basic computer education in accounting vocational colleges, this article has stated the necessity of the layered-teaching-in-one-class teaching mode and investigated the current problems with this mode for basic computer education in these colleges.

Most vocational colleges have realized the hierarchical teaching of computer basic course, that is, to clarify the necessicity, significance and implementation of hierarchical teaching to the newly-entered students. Then the students enroll for placement test, go different classes according to their scores and receive different education. Obviously, this hierarchical teaching is feasible for colleges with rich teaching resources while it is unpractical for the others. Therefore, it must be realistic to conduct the hierarchical teaching of computer basic course. With the accounting major of Chongqing Business Vocational College as an example, a brand new "layered-teaching-in-one-class" mode has been put forward in this article.
\end{abstract}

\section{Features of the present basic computer education in accounting vocational colleges}

With the rapid development of the computer technology, network technology and communication technology, we humans have stepped into an information era in which computers can be found in most families and industries, and its wide use has been part of our work and life. Therefore, accountants of this era should have a background knowledge of both accounting and computer. Because of the popularity of computer course in middle and primary school, most of the newly-entered students have had the basic but varied computer application ability. Thus, their computer basic course in vocational colleges should differ from that of the middle and primary school, and be integrated tightly with their professional knowledge. The present basic computer education in accounting vocational colleges is characterised by the following features:

Unclear teaching objectives

For the computer basic course, different departments are characterised by different training objectives. And the formulation and implementation of teaching plans are different, too. The present computer basic course focuses on the operation systems, office software and internet, but there is no obvious difference between different departments. For the accounting major of vocational college, the accounting courses are the most important while the computer basic course is the public basic course, and the accounting students can not understand how computers are applied in practice.

Shortage of professional teaching staff

Although most computer teachers are capable of professional teaching courses, we still need some teachers who are familiar with both the computer knowledge and the accounting knowledge for integrating the application of computers with accounting work. As a matter of fact, such teachers are in urget demand in many vocational colleges.

The conflict between the enlarging teaching task and declining teaching time

With the developmentof computer technology and its integration with other disciplines, the task of computer courses is enlarging, while the teachers have less and less teaching courses. In order to solve this problem, we shoud choose teaching materials that are practical and closely connected 
with the professional knowledge.

\section{The necessity of "layered-teaching-in-one-class" for computer basic course of the accounting major}

Through the investigation of the Grade 09, Grade 10 and Grade 11in our school, we found that most students come from rural areas, they have different degrees of computer knowledge, and their computer application abilities are quite different from each other. Consequently, the students' various computer basic knowledge adds to the teaching difficulty. Besides, with the popularity of computer knowledge, there are more and more students who have access to computers, and the old-fashioned teaching mode will have negative effects.

The computer basic course has been compulsory for students of all vocational colleges, and it is necessary to reform the teaching methods to enhance their capabilities of computer application, among which the layered teaching has been the most fruitful attempt. At present, most colleges divide their freshmen into different classes according to their performance of the computer test. However, this layered teaching mode will bring about difficulty in teaching and management for our school as a result of our limited teaching resources. Therefore, it is necessary to explore the layered-teaching-in-one-class which is more applicable.

Under the so-called "layered-teaching-in-one-class" for computer basic course, the students are grouped into the application level and the expansion level according to their actual conditions and the teaching programme, and then receive different tutoring and tests. This mode aims at promoting the teaching efficiency, comprehensively improving the students' quality and fulfilling the teaching tasks.

\section{A probe into the "layered-teaching-in-one-class" for computer basic course of the accounting major in vocational college}

How to straitify the students dynamically

It is an important step for the layered-education management to straitify the students dynamically. Its objectivity and scientificity directly influence the realization of teaching target and effect. With different intelligence, capabilities, interest and will, the students, who are the subject of the whole teaching process, will have different study effects. It is important to note that the students' characteristics can be explicit or implicit. It is necessary to know about and study the students to achieve the target of "layered-teaching-in-one-class". The correct approach is to make longtitudinal comparison of the students' capabilities and stratify them dynamically according to certain learning period and teaching task. For example, the students of the application level with outstanding performance can be moved to the expansion level to arouse his learning initiative.

To make reasonable teaching contents and procedure

In a sense, the layered-teaching-in-one-class will increase the teachers' work as they need to consider students' various computer application capabilities. To be exact, the learning capability and progress of the application level students, and the learning initiative of the expansion level students, both need to be taken into consideration. Therefore, the arrangement of teaching contents should reflect the application skills as well as the expansion capabilities. Such a teaching mode will do good for the students' academic achievements, satisfy their psychological needs, promote the students' comprehensive capabilities and form a harmonious learning complexion.

To adjust the students' mindsets

As a practical course, the learning effect of the computer basic course has a great deal to do with the students' attitude, motive, interest, character and so on. All teachers should set up fresh student and teaching viewpoints, know about the students' mindsets, and respect and love them. We should encourage and help students of the application level, guide and inspire students of the expansion level, and pay attention to students with wavering attitude and performance. A good student-teacher relationship is an effective guarantee for smooth layered teaching, and it calls for sincere and equal respect to the students. 
To set up evaluation systems for students and teachers

When conducting the layered-teaching-in-one-class, we should advocate the layered test, periodic test and independent test, and build a new thinking mode of test -select but not eliminate. The process evaluation will be primary, and the periodic evaluation and final evaluation supplementary. The students are straitified according to their capabilties and attitudes, and they should also be evaluated by their performance, that is, to encourage the students of the application level with good performance and criticise those of the expansion level with low learning initiative. And the teachers should be evaluated through the students' scores and the performance of the whole class.

\section{The existing problem of the "Layered-Teaching-in-One-Class" for computer basic course of accounting vocational college}

Increased work for teachers

Because of the rapid development of computer hardware and software, there is no approriate material for layered teaching. Therefore, it is necessary for the computer teachers to compile and write teaching material fit for the layered-teaching-in-one-class. Meanwhile, the teaching organization and classroom management will be more difficult and complex.

Negative effects to the students' psychology

The straitification of students will inevitably affect their psychology. Some students will be proud of their higher level and some will feel inferior for their lower level. Such feelings will influence their college life or even their whole life.

\section{Conclusion}

As the computer basic course of vocational college is aimed at practical computer talents of various fields, the vocational colleges should integrate the computer course with different majors to adapt to the development trend of the future society. In this new era, the teachers of the computer major are required to accumulate teaching experiences, know about computer application knowledge and understand the industrial demands to serve the computer teaching.

The layered-teaching, with students as its subject, will promote their all-round development and enhance the teaching effect. The straitification originates from the difference and diversity of students, and the teaching effect comes from the straitification. However, the layered-teaching, with its shortcomings, needs to be further improved in research and practice to fully play the role of the computer basic course.

(Comment: one of the research results of the 2011 municipal elaborate courses - Basics of Computer Applications(accounting) in colleges and universities of Chongqing. )

\section{References}

[1] Wang Yanhua: The Teaching Reform and Innovation of Computer Application Basis in Vocational College. Education for Chinese After-school(Theory), Vol.1(2009), p. 126

[2] Zhao Li, Yu Liping: The Design and Application of Grading Teaching Mode of Basic Computer Course in Vocational College. Journal of Xinjiang Vocational University, Vol. 5(2008), p. 68-70

[3] Fan Lili: On the Teaching Reform of Computer Application Basis Course in Vocational College .Science and Technology Information, Vol. 24(2009), p. 154

[4] Xu Xuejun: A Probe of the Application of Layered-teaching in Chinese Vocational College .Journal of Hubei University of Economics, Vol. 4(2008), p. 174-175 